department responsible for financial control should also bo responsible for policy and management of personnel, since it is judge in its own cause: considorations of finance may take precedence over ideas of onlightened management. Whether in fact that happens seems a little doubtful on the evidence of the Estimates Committee's report, but the function of the Treasury as viewed by the Fabian Group should be considered in the light of its proposal to transfor to the Civil Service Commission the responsibility for personnel management and the structure of the Civil Service. For that, however, the pamphlet must be considered in greater detail, and all that can be added here is that, like the Estimates Committee itself and $\mathrm{Mr}$. Hill and $\mathrm{Mr}$. Whicholow in discussing the reform of Parliament, the Fabian Group is intensely concerned with the recruitment and use of scientists on an adequate scale and up to the highest levels.

\section{THE INTERNATIONALE OF SCIENTISTS}

\section{The Dawn of a New Age}

Reflections on Science and Human Affairs. By Eugene Rabinowiteh. Pp. viii +332 . (Chicago and London: University of Chicago Press, 1963.) 6.95 dollars; $52 s$.

T HIS book by the internationally known, respected and loved editor of the Bulletin of the Atomic Scientists contains his reflexions on human affairs extending over almost twenty-five years. He first presents his credentials as a prophet in two astonishingly accurate forecasts of the Second World War, written on September 1, 1939, and on May 5, 1941. After this it comes as less of a surprise that in his later essays, written at the time of the Korean war, of the Vietnam crisis, of the first Sputnik and of the Cuban erisis, ho has displayed the same sound judgment; always confirmed, never contradicted by what has happened since then.

Eugene Rabinowitch was born in the U.S.S.R. and is now professor of biophysics at the University of Illinois. $\mathrm{He}$ has maintained friendly relations with a great number of Soviet scientists, without ever ceasing to be critical of their system. His essay on "Russian and Soviet Science" is a masterpiece of balanced judgment. In this, and in all his other essays collected in this volume, he pleads a realistic gospel of understanding and of patience, which is probably equally uncongenial to the average unsophisticated American with a somewhat fundamentalistic cast of mind, who ean see nothing but diabolic wickedness in Communism, and to the fundamentalists among his fellow-scientists, who recommend conscientious objoction, and who can see no hope short of "Banning the Bomb".

Rabinowitch is a Fabian of disarmament, who keeps his eye steadfastly on what is possible, without ever forgetting the final goal. The report to the Secretary of War, 1945, of which he was one of the chief authors, and which has become known as the Franck Report, and his speech for the President in 1954, are fine examples of his method of approaching influontial non-scientists. If not even words of such wise moderation so closely argued from incontrovertible facts have an effect on politicians, then what use aro words? Rabinowitch must havo ofton asked himself this quostion, yet he has never despaired, and never given up his pationt pleading. If, as is very likely, he and people like him have made even a small contribution to the tremendous fact that fifteen years after both sides came into possession of the atomic weapon not a single nuclear bomb was exploded in anger, this ought to be considerod a rich reward for their patience.

The book contains thirty essays, grouped undor the headings "Looking Ahead", "Taking Stock", "Talking with World Scientists", and "Heretical Thoughts".
If anybody looks for really heretical thoughts, he will be disappointed. Rabinowitch offers plain common sense, and he scorns Bernard Shaw's trick of dishing up commonsense as a shocking paradox. It is somewhat regrettable, but in the nature of things, that out of his many pages of carefully balanced arguments, it will be scarcely possible to lift out even one epigram, which might take root in the common man's mind. He is a fluent and polished writer, eminently readable, yet sometimes I wish he had taken advice from 'Mad. Ad.'. But any serious reader, scientist or humanist, will find great enjoyment in reading his book.

D. GABOR

\section{PHYSICIAN AND PHILOSOPHER}

John Locke (1632-1704): Physician and Philosopher A Medical Biography, with an Edition of the Medical Notes in his Journals. By Kenneth Dewhurst. Pp. xii $+331+11$ plates. (London: The Wellcome Historical Medical Library, 1963.) $42 s$.

OHN LOCKE'S abiding fame rests on his philosophy. $\int \mathrm{He}$ may be regardod as the founder of empiricism, which is the doctrine that all our knowledge (with the possible exception of logic and mathematics) is founded on experience. He was born in 1632, but did not publish the Essay Concerning Human Understanding until 1687 Six years (1687-1693) sufficed for this and his further works on Toleration, Government and Education to mako him the most influential and perhaps the greatest of British philosophers. His teaching in his lifetime and after his death exerted a far-reaching political influence. The British Constitution was based on Locke's doctrines until some sixty years ago; with Montesquieu's additions they are part of the American Constitution; they had a determining influence for the French philosophers and the moderate reformers in the French Revolution and inspired the French Constitution in $1871^{1}$.

So great is Locke's stature as a philosopher that it is often forgotten that he was also a scientist, and throughout the greater part of his life a practising physician, a writer of medical essays and of clinical reports and papers. The view may well be accepted that it was his interest in science and prolonged observation of disease that lod him to reflect on human knowledge and to enunciate his views that this equally was based on experience.

When Locke died, his large store of manuscripts, notebooks and journals went to his cousin, Peter King, later Lord Chancellor. The seventh Lord King, in 1829, published an indifferent biography, entitled Life and Letters of John Locke, with a few extracts from the journals. The medical aspect of Locke's life was brought forward in Dr. John Brown's discursive essay, "Locke and Sydenham" (Horae Subsecivae, 1866). In 1876, H. R Fox Bourne's reliable biography, the Life of John Locke, appeared in two volumes, which examined new material including some of Locke's medical writings. This led to the brief but admirablo studies of two medical historians. Dr. E. T. Withington ${ }^{2}$ and Sir William Osler ${ }^{3}$, who both concluded that Locke was an experienced and skilful physician of sound judgment and advanced views. They surmised that he gave more time to his chosen profession than the manuscripts then disclosed. Theso beliefs were confirmed in 1948, when the Bodleian Library, with the aid of the Clarendon Press, purchased from the Earl of Lovelace (a descendant of the first Lord King) a large collection of Locke's unpublished papers including much material of medical interest.

Dr. K. Dewhurst, Wellcome Research Fellow in medicine, Corpus Christi College, Oxford, has sedulously studied and deciphered the medical papers in this new source of material and has written this scholarly medical biography of John Locke, which reveals the philosopher's attainments as scientist and physician. Included are 